\title{
A new species of Urophora Robineau-Desvoidiy, 1830 (Diptera, Tephritidae) from Iran
}

\author{
Saeed Mohamadzade Namin ${ }^{1, \dagger}$, Jamasb Nozari ${ }^{2, \neq}$ \\ I Department of Plant Protection, Faculty of Agriculture, Varamin-Pishva branch, Islamic Azad University, \\ Varamin, Iran 2 Department of Plant Protection, Faculty of Agriculture, University of Tehran, Karaj, Iran \\ † urn:lsid:zoobank.org:author:9063C413-5D65-44B7-9B94-E17684660E96 \\ ¥urn:lsid:zoobank.org:author:D70429BD-0695-4A8A-8793-D84E45FF8C28 \\ Corresponding author: Saeed Mohamadzade Namin (mohamadzade@iauvaramin.ac.ir)
}

Academic editor: R. Meier | Received 13 August 2011 | Accepted 3 November 2011 | Published 8 December 2011

urn:lsid:zoobank.org:pub:F30D708A-9B83-44F0-8DAE-F8163650EE71

Citation: Mohamadzade Namin S, Nozari J (2011) A new species of Urophora Robineau-Desvoidiy, 1830 (Diptera, Tephritidae) from Iran. ZooKeys 152: 63-70. doi: 10.3897/zookeys.152.1911

\begin{abstract}
Urophora merzi sp. n. reared from flower heads of Centaurea behen Linnaeus is described from Iran. It is similar to U. campestris, $U$. sachalinensis, U. stylata, U. tsoii and $U$. vera in wing pattern with 3 well developed crossbands and indistinct subbasal crossband, differing in aculeus tip with two pairs of diminished preapical steps and different host plants.
\end{abstract}

\section{Keywords}

Tephritidae, Urophora, new species, Iran

\section{Introduction}

The genus Urophora Robineau-Desvoidiy, 1830 with about 60 species is one of the largest genera of the family Tephritidae in the Palaearctic Region (Norrbom et al. 1999). All species of known biology are associated with asteraceous plants and induce galls in their flower heads and, rarely, stems (White and Korneyev 1989). Some Urophora species are agents for biological control of astraceous weeds; U. affinis (Frauenfeld), $U$. 
cardui (Linnaeus), U. quadrifasciata (Meigen), U. sirunaseva (Hering), U. solstitialis (Linnaeus) and U. stylata (Fabricius) successfully introduced to the Nearctic Region for biocontrol of weeds (Peschken and Harris 1975; Turner et al. 1994; Turner 1996 a, b; Wheeler and Stoops 1996).

While studying the tephritid flies fauna in Iran in 2008-2011 seasons, we collected and reared a previously undescribed species that infests the flower heads of Centaurea behen L. (Asteraceae). The new species is described and figured below.

\section{Material and methods}

Materials were collected by standard sweeping net and rearing from flower heads of Centaurea behen. Morphological terminology follows White et al. (1999). The material examined minuten-pinned on side and deposited in collections of the following institutions:

JAZM Jalal Afashar Zoological Museum, College of Agriculture, University of Tehran, Karaj, Iran.

MHNG Museum d'histoire naturelle, Genève, Switzerland.

SIZK I. I. Schmalhausen Institute of Zoology, National Academy of Sciences of Ukraine, Kiev, Ukraine.

ZISP Zoological Institute, Russian Academy of Sciences, St. Petersburg, Russia.

The following morphometric characters with their abbreviations are used: Body length (BL); wing length (WL); aculeus length (AL).

\section{Results}

Key to Western Palaearctic species of Urophora with the stylata-like wing pattern (3 distinct crossbands, of them, apical and subapical fused)

(Corresponding to the couplet 94 in Korneyev and White 1999)

1 Apex of aculeus with two pairs of indistinct steps (Fig. 6); associated with Centaurea behen U. merzi sp. n.

- $\quad$ Apex of aculeus with 1-2 pairs of prominent primary steps. 2

2 Apex of aculeus with 1 pair of prominent primary steps 3

- $\quad$ Apex of aculeus with 2 pairs of prominent, sharp steps (see couplet 97 in Korneyev and White 1999)

3 Apex of first flagellomere slightly pointed. Aculeus width between primary steps almost equal to distance from primary steps to apex (see Korneyev and White 1996: Fig. 21). Larvae in Serratula flower head galls. Armenia 
- $\quad$ First flagellomere apically rounded. Aculeus apex between primary steps almost twice as wide as its length from primary steps level to tip (see Korneyev and White 1996: Fig. 17). Larvae in Cirsium flower head galls. Whole Europe and Western Asia to West Siberia and western China.... U. stylata Fabricius

\section{Urophora merzi Mohamadzade Namin, sp. n.}

urn:lsid:zoobank.org:act:2A468C69-CE7C-4C69-BE53-06168D739915

http://species-id.net/wiki/Urophora_merzi

Figs $1-15$

Type material. Holotype (female): Iran: Mazandaran Province, Haraz road, $10 \mathrm{~km}$ north east Abali, $35^{\circ} 50^{\prime} \mathrm{N}$; 51 $58^{\circ} \mathrm{E}$, h $2360 \mathrm{~m}$, swept from flower heads of Centaurea behen, 20 May, 2011, S. Mohamadzade Namin leg. (JAZM).

Paratypes: 1 , , same collection data as in holotype, reared from flower heads of Centaurea behen Linnaeus, collected 13 September, 2008 \& emerged 22 September 2008; 1 ô, 1 ㅇ, Alburz Province, Chaloos road, Nesa, 36 $04^{\prime} \mathrm{N} ; 51^{\circ} 19^{\prime} \mathrm{E}, \mathrm{h}$ $2200 \mathrm{~m}$, 22 June 2009, swept from Centaurea behen; 15 ऽ, 18 ㅇ, same collection data as in holotype, 20 May, 2011, S. Mohamadzade Namin leg. (JAZM; some paratypes are deposited also in MHNG, SIZK, ZISP and first author's personal collection).

Description. Head: Yellow, except ocellar triangle, occiput and slender part of arista black. Length: height: width ratio $=1: 1: 1.25$. Frons brown; face whitish yellow; Antenna yellow, scape with blackish setulae at dorso-apical margin; first flagellomere light yellow, 1.6 times as long as wide and distinctly rounded antro-ventrally; arista bare. Compound eye about as high as long. Gena 1.1 times as high as length of first flagellomere. Proboscis capitate with black setae. Two frontal and one orbital setae present. Postocellar, postocular, vertical and genal setae black and acuminate. Frons with black setulae around frontal setae (Fig. 4).

Thorax: General color black; mesonotal scutum densely covered with gray microtrichia and black setulae. Notopleura shining black. Pleuron black; only stripe in anterior half of anepisternum and postpronotal lobe yellow. Scutellum yellow; slightly convex, corners of scutellum black. Subscutellum and mediotergite black. All setae on thorax black and acuminate. Scutellum with 4 equal black setae; basal setae placed in yellow area. Halter yellow.

Wing: Hyaline with 3 well developed dark brown crossbands. Subbasal band reduced and only present as darkening near apex of cell bm and rarely bcu. Discal crossband complete, crossing wing from pterostigma through R-M crossvein into posterior margin. Preapical crossband complete, reaching posterior margin. Apical band well developed. In females, preapical and apical crossbands in $56.2 \%$ of type material fused in cell $r_{1}$ (Fig. 2), in 31.2\% fused in $r_{1}$ and $r_{2+3}$ (Figs 1, 11) and in $12.5 \%$ fused in $r_{1}$, $r_{2+3}$ and anterior half of $r_{4+5}$ cells (Fig. 3). In males, preapical and apical crossbands in 

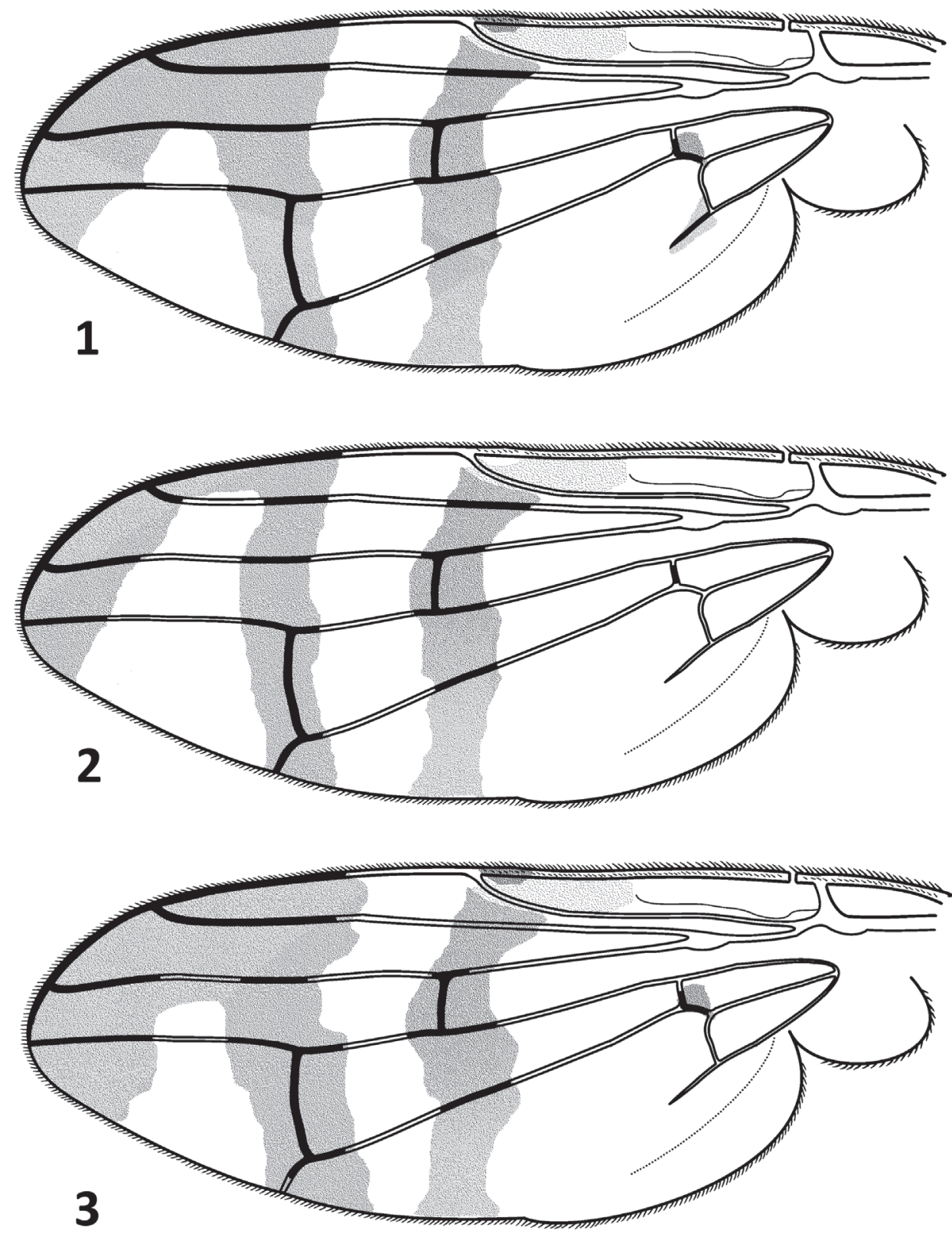

Figures I-3. Urophora merzi sp. n., I wing pattern of the holotype 2-3 variation of wing pattern in paratypes.

$33.3 \%$ of specimens fused in cell $\mathrm{r}_{1}$, in $50 \%$ fused in $\mathrm{r}_{1}$ and $\mathrm{r}_{2+3}$ and in $16.6 \%$ fused in $\mathrm{r}_{1}, \mathrm{r}_{2+3}$ and anterior half of $\mathrm{r}_{4+5}$ cells. In one male of type series discal and preapical crossbands narrowly joined in $\mathrm{r}_{1}$ cell and in one female and one male discal and preapical crossbands narrowly connected at posterior margin of wing. Pterostigma yellowish. 


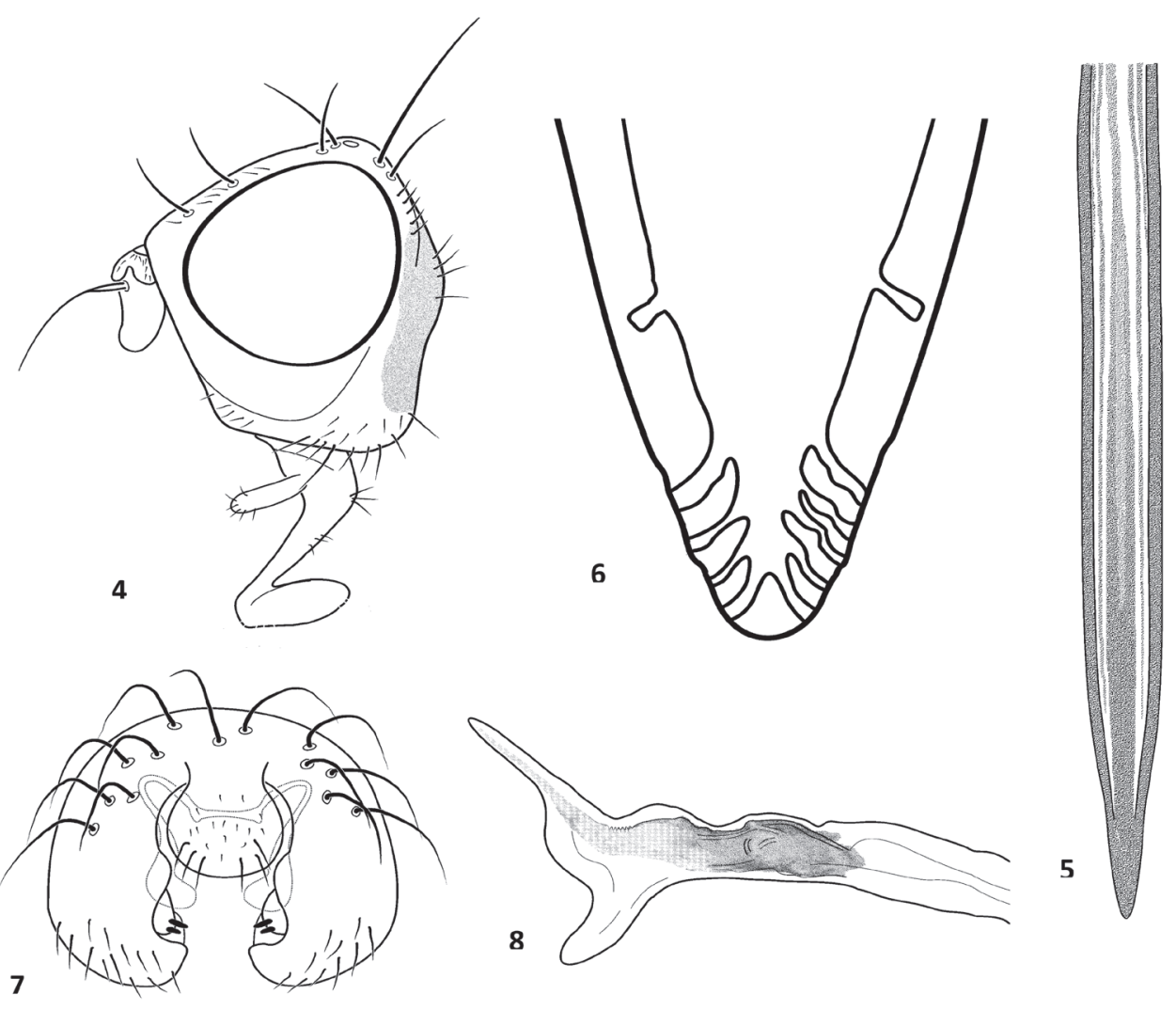

Figures 4-8. Urophora merzi sp. n., $\mathbf{4}$ head in profile $\mathbf{5}$ aculeus $\mathbf{6}$ aculeus tip $\mathbf{7}$ male terminalia $\mathbf{8}$ epandrium.

Distance between crossveins about 1.4 as long as $\mathrm{dm}$-cu crossvein. $\mathrm{R}_{4+5}$ with 1 setula ventrally at node.

Legs: Completely yellow; fore femur in $60 \%$ of females and $55 \%$ of males with black stripe in dorsal side. All setae and setulae blackish (Figs 9, 10). Fore femur with two dorsal and one ventral rows of setae.

Abdomen: General color black, sparsely microtrichose, subshining with black setulae. Posterior margin of abdominal tergites, especially tergites 5-6 with long black setae. Oviscape 1.25 times as long as preabdomen, shining black with black hairs. Aculeus narrow, 11 times as long as wide, apically rounded, apex with two pairs of indistinct steps, as in Figs 5 , $6,13,14$. Tergite 5 of males as long as two preceding tergites with long setae in posterior margin. Epandrium as in Figs 8, 12 and glans as in Figs 7, 15.

Measurements: Male: $\mathrm{BL}=3.5-4 \mathrm{~mm}$ (average 3.8), $\mathrm{WL}=3.5-4.5 \mathrm{~mm}$ (average 3.9); female: $\mathrm{BL}=4.5-6 \mathrm{~mm}$ (average 5.3), $\mathrm{WL}=4-4.9 \mathrm{~mm}$ (average 4.3), $\mathrm{AL}=1.5-2$ $\mathrm{mm}$ (average 1.9) $(\mathrm{n}=5)$.

Etymology. The species is named in honour of Dr Bernhard Merz, an outstanding Swiss dipterist, in recognition of his invaluable contribution into study of the order Diptera, especially family Tephritidae. 

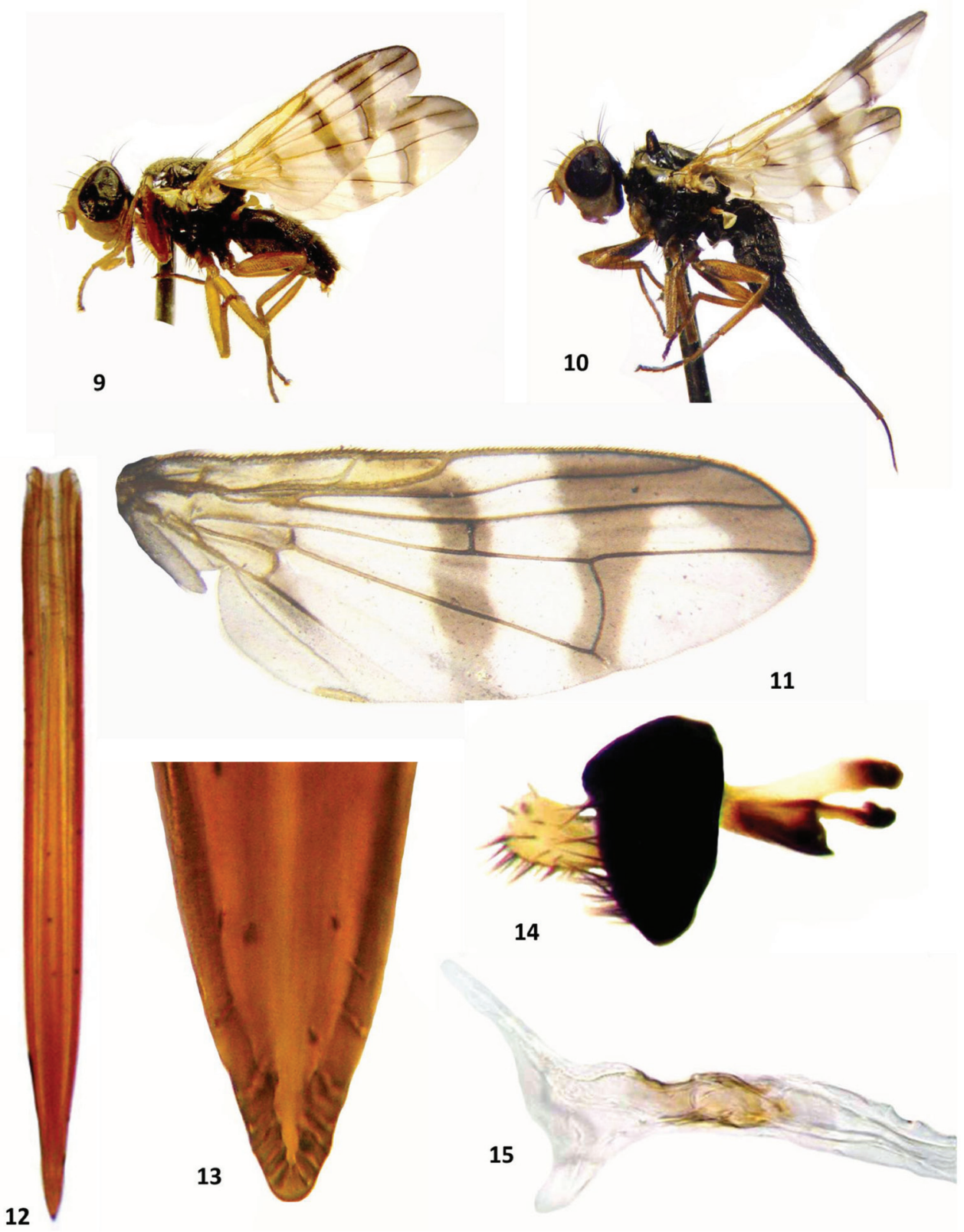

Figures 9-15. Urophora merzi sp. n., $9 \widehat{\partial}$, total view, left $\mathbf{I} 0$ (Holotype), total view, left II wing pattern (Holotype) $\mathbf{1} \mathbf{2}$ aculeus $\mathbf{I} \mathbf{3}$ aculeus tip $\mathbf{1} \mathbf{4}$ epandrium $\mathbf{I} \mathbf{5}$ male terminalia.

Discussion. The new species is similar to $U$. campestris Ito (Japan), $U$. sachalinensis (Shiraki) (Russia and Japan), U. stylata Fabricius (Worldwide), U. tsoii Korneyev and White (Russia) and U. vera Korneyev and White (Armenia), sharing similar wing pattern (3 well developed crossbands and indistinct subbasal crossband, with apical and preapical crossbands fused along anterior margin of wing), yellow femora and antenna and black 
notopleura, differing in the shape of aculeus apex. Apex of aculeus in $U$. sachalinensis, $U$. stylata and $U$. vera has one pair of steps. $U$. campestris and $U$. tsoii (both occurring in the Far East of the Palaearctic Region) possess two pairs of distinct steps, whereas the aculeus tip in $U$. merzi sp. n. has two pairs of smoothed, almost indistinct steps. Also the new species is similar to $U$. jaculata Rondani (Italy and Greece), sharing similar aculeus apex and host plants of the genus Centaurea, differing in the subbasal crossband strongly reduced to a darkening near bm cell (distinct and reaching $\mathrm{R}_{1}$ in $U_{\text {. jaculata). }}$

All the compared species are associated with different host plants: $U$. campestris, $U$. sachalinensis and $U$. stylata are associated with Cirsium spp., Carduus spp. and Galactites tomentosa; $U$. tsoii and $U$. vera with Serratula spp. and $U$. jaculata with Centaurea solstitialis (Korneyev and White 1999, 2000) whereas U. merzi sp. n. is associated with Centaurea behen.

\section{Acknowledgments}

We wish to express our gratitude to Islamic Azad University Varamin-Pishva branch (Grant title: Faunistic study of fruit flies of family Tephritidae in West Azerbaijan and Mazandaran Provinces) for the support of this work. We thank Dr Valery A. Korneyev (Schmalhausen Institute of Zoology, NAS of Ukraine, Kiev, Ukraine) for reading early versions of this manuscript and suggesting many useful remarks. We are grateful to Mr. Masoumi (University of Tehran, Faculty of Horticulture) for identification of the host plant.

\section{References}

Korneyev VA, White IM (1996) Fruit flies of the genus Urophora R.-D. (Diptera, Tephritidae) of Eastern Palaearctics. II. Review of species of the subgenus Urophora s. str. Communication 3. Entomological Review 76(4): 499-513.

Korneyev VA, White IM (1999) Tephritids of the genus Urophora R.-D. (Diptera, Tephritidae) of East Palaearctic: III. Key to palaearctic species. Entomological Review 78(3): 464-482.

Korneyev VA, White IM (2000) Tephritids of the genus Urophora R.-D. (Diptera, Tephritidae) of East Palaearctic: IV. Conclusion. Entomological Review 79(1): 239-253.

Norrbom AL, Carroll LE, Thompson FC, White IM, Freidberg A (1999) Systematic Database of Names. In: Thompson FC (Ed) Fruit Fly Expert Identification System and Systematic Information Database. Myia, 65-299.

Peschken DP, Harris P (1975) Host specificity and biology of Urophora cardui (Diptera: Tephritidae). A biocontrol agent for Canada thistle (Cirsium arvense). Canadian Entomologist 107: 1101-1110. doi: 10.4039/Ent1071101-10

Turner CE, Sobhian R, Joley DB, Coombs EM, Piper GL, Maddox DM (1994) Establishment of Urophora sirunaseva (Hering) (Diptera: Tephritidae) for biological control of yellow starthistle in the western United States. Pan-Pacific Entomologist 70: 206-211. 
Turner CE (1996a) Tephritidae in the biological control of weeds. In: McPheron BA, Steck GJ

(Eds) Fruit fly pests: Aworld assessment of their biology and management. St. Lucie Press, Delray Beach, 157- 164.

Turner CE (1996b) Tephritid flies in the biological control of yellow starthistle. In: McPheron

BA, Steck GJ (Eds) Fruit fly pests: Aworld assessment of their biology and management.

St. Lucie Press, Delray Beach, 171-176.

Wheeler AG, Stoops CA (1996) Establishment of Urophora affinis on spotted knapweed in Pennsylvania, with new eastern U.S. records of U. quadrifasciata (Diptera: Tephritidae). Proceedings of the Entomological Society of Washington 98: 93-99.

White IM, Korneyev VA (1989) A revision of the western Palaearctic species of Urophora

Robineau-Desvoidy (Diptera: Tephritidae). Systematic Entomology 19(3): 327-374. doi: 10.1111/j.1365-3113.1989.tb00289.x

White IM, Headrick DH, Norrbom AL, Carroll LE (1999) Glossary. In: Aluja M, Norrbom AL (Eds) Fruit Flies (Tephritidae): Phylogeny and Evolution of Behaviour. CRC Press, Boca Raton, London, New York, Washington DC, 881-924. doi: 10.1201/9781420074468.sec8 